\title{
POTENSI BAKTERI INDIGENOUS PADA TANAH TAILING KECAMATAN MANDOR DALAM REMEDIASI METIL MERKURI
}

\section{THE POTENTIAL OF INDIGENOUS BACTERIA FROM TAILING AREA AT MANDOR DISTRICT TO METYL MERCURY REMEDIATION}

\author{
Rezekikasari ${ }^{(1)}$, Sutarman Gafur, ${ }^{(2)}$ dan Rini Susana ${ }^{(2)}$ \\ (1) Ilmu Lingkungan, Universitas Tanjungpura, Pontianak 78124 Indonesia \\ (2) Fakultas Pertanian, Universitas Tanjungpura, Pontianak 78124 Indonesia
}

Email: rezekikasari@gmail.com

\begin{abstract}
ABSTRAK
Kecamatan Mandor memiliki banyak lahan penambangan emas baik yang aktif digunakan maupun yang telah ditinggalkan. Wilayah-wilayah yang pernah dibuka sebagai tempat usaha penambangan emas tidak pernah diupayakan untuk membersihkan sisa-sisa merkuri yang digunakan sebagai bahan pemisah butiran emas baik oleh pihak pemerintah, swasta maupun perorangan. Akibatnya wilayah ini menjadi lahan kritis yang rawan dampak pencemaran wabah penyakit yang disebabkan oleh paparan metil merkuri. Penelitian ini bertujuan mengeksplorasi bakteri yang berasal dari Kecamatan Mandor dan memiliki kemampuan mereduksi metil merkuri secara in vitro. Isolat yang diperoleh adalah isolat yang dapat dijadikan sebagai agent yang mampu memulihkan lahan yang tercemar metil merkuri. Penelitian dilakukan pada skala laboratorium dan diperoleh sebanyak 20 isolat yang tersebar dari beberapa lokasi pengambilan sampel. Isolat bakteri ditumbuhkan dengan menggunakan metode tuang yang menggunakan media nutrien agar. Dari 20 isolat yang ditemukan 6 diantaranya adalah isolat yang memiliki kemampuan hidup pada media yang ditambahkan metil merkuri mulai taraf konsentrasi 5 ppm, 10 ppm dan 15 ppm Hg.
\end{abstract}

Kata kunci : Bakteri Indigenous, metil merkuri dan tailing.

\begin{abstract}
Mandor district has lot of gold mining, both of which are still actively pursued or are not used anymore. In the area that was used as gold mining never attempted to clean of the mercury residual, either by the government, private, or individual. Mercury was used to separate between the gold and sand. Over the time this land became degrade, and can be a source of disease caused by exposure to mercury. This research aims was to explore the bacteria in gold mining land at Mandor that has the ability to reduce methyl mercury. The bacterial isolates obtained can be used as agent that can recover mercury contaminated land. Isolation of bacteria used dilution plate method on nutrient agar media. It's found 20 isolates, 6 of which have ability to reduce methyl mercury at concentration 5 ppm, 10 ppm and $15 \mathrm{ppm}$.
\end{abstract}

Key word: Indigenous Bacteria, Methyl Mercury and Tailing.

\section{PENDAHULUAN}

Beberapa daerah di Kalimantan Barat juga mengalami lahan kritis akibat penambangan emas tanpa izin seperti yang terjadi di Kecamatan Mandor Kabupaten Landak. Berdasarkan luas data spasial dari Peta penggunaan Lahan tahun 2013, kerusakan lahan akibat PETI pada kawasan ini mencapai 
$11,25 \%$ dari total luas wilayah $15.463,62$ hektar atau setara dengan 1.739 ha.

Kawasan bekas pertambangan dapat dipergunakan sebagai upaya untuk menopang ketahanan pangan lokal, asalkan dapat dipastikan konsentrasi metil merkuri di lahan tersebut sudah berkurang, hilang atau tidak berbahaya lagi bagi mahluk hidup. Lahan bekas tambang PETI (Penambangan Emas Tanpa Izin) yang telah mengalami tingkat degradasi yang tinggi akibat pencemaran merkuri sangat sulit untuk dipulihkan kondisinya. Pemulihan dengan memanfaatkan mikroba pada lingkungan karena adanya ekstraksi logam dipandang lebih ekonomis dan ramah lingkungan dibanding cara lain (Rawling dan Silver, 1995 dalam Rawling 2004). Pemulihan lahan yang berjalan dengan sendirinya atau secara alami jika lingkungan memadai, dikenal dengan istilah daya lenting. Bantuan mikroba yang kompatibel dan efektif dapat membantu pemulihan lingkungan dengan cepat, aman dan murah, hingga pada akhirnya lahan-lahan tersebut dapat dipergunakan kembali untuk lahan perkebunan dan budidaya pertanian. Metode tersebut dikenal dengan istilah bioremediasi atau dengan cara memanfaatkan bakteri lokal yang mempunyai kemampuan mereduksi metil merkuri. Spesies bakteri yang diduga mempunyai kemampuan dalam mereduksi metil merkuri diantaranya adalah Pseudomonas sp., Klebsiella, Thiobacillus, Orchrobactrum sp., Staphilococcus aureus, Bacillus sp., dan E.Coli (Ijong dkk, 2011). Penanganan lahan tercemar dengan metode bioremediasi merupakan pendekatan potensial yang efektif dan murah secara ekonomis dibanding teknik aplikasi lain (Onrizal, 2005). Campur tangan manusia diperlukan supaya lingkungan mampu mendukung berlangsungnya proses bioremediasi secara cepat, atas dasar itu penelitian ini dianggap perlu untuk dilakukan.

Lahan-lahan bekas penambangan yang telah ditinggalkan oleh penambang, bervariasi kurun waktunya, mulai dari satu tahun sampai puluhan tahun. Lahan ini umumnya tercemar merkuri dari sisa pengolahan emas. Kandungan merkuri yang tertinggal pada lahan-lahan tersebut juga akan bervariasi konsentrasinya. variasi tersebut diakibatkan oleh keberadaan bakteri yang mempunyai kemampuan untuk mereduksi lahan yang tercemar merkuri dengan konsentrasi tinggi menjadi berkurang atau melemah tingkat toksisitasnya. Hasil penelitian Ferianto, dkk (2013) menunjukkan kadar merkuri pada dasar sungai Kecamatan Mandor yang telah ditinggalkan 4-5 tahun adalah 0,020 ppm, 6-10 tahun 0,050 ppm dan 11-15 tahun $0,037 \mathrm{ppm}$.

Lahan yang telah lama ditinggalkan membuat bakteri akan beradaptasi dalam jangka waktu tersebut atau telah terjadi suksesi ekologis dimana bakteri dapat beradaptasi dengan kondisi lingkungannya. Resistensi tersebut terjadi dengan mekanisme detoksifikasi yaitu serangkaian usaha sel bakteri menjadi resisten terhadap merkuri yang berlangsung sangat komplek meliputi presipitasi dan kristalisasi logam berat yang terjadi pada intra dan ekstraseluler mikrobia (Gadd, 2000). Lahan yang tercemar oleh logam berat dapat dipulihkan dengan berbagai cara diantaranya melalui proses bioremediasi yaitu suatu metode dengan memanfaatkan keberadaan bakteri setempat untuk pemulihannya.

Kehidupan bakteri pada suatu lingkungan umumnya melalui beberapa fase, yaitu fase adaptasi atau eksponensial, fase stasioner dan fase kematian. Fase adaptasi merupakan fase pertumbuhan dimana bakteri berusaha menyesuaikan diri dengan lingkungannya. Fase ini merupakan fase paling cepat dan paling aktif dengan metabolisme dan sintesa bahan sel. Fase stasioner merupakan kondisi stagnan dimana jumlah bakteri yang hidup dengan yang mati berimbang karena ketidakmampuan untuk beradaptasi. Fase kematian adalah fase bakteri mulai kehabisan nutrisi untuk pertumbuhannya (Zulaika, dkk. 2012). Karakterisasi dari bakteri yang ditemukan sangat penting diketahui untuk memahami bagaimana bakteri tersebut mereduksi metil merkuri. Kadar merkuri yang tertinggal pada tanah bekas penambangan berdasarkan perbedaan kurun waktu pengunaan lahan penambangan yang masih digunakan dengan yang sudah ditinggalkan, akan diketahui dengan melihat indikasi kemampuan bakteri lokal Kecamatan Mandor dalam mereduksi metil merkuri. 


\section{METODE}

Penelitian dilaksanakan di Laboratorium Biologi dan Bioteknologi Tanah Fakultas Pertanian Untan. Pengambilan sampel tanah di desa Mandor Kecamatan Mandor Kabupaten Landak. Penelitian dilaksanakan pada bulan Maret sampai dengan Mei 2015.

Peralatan yang dipakai dalam penelitian terdiri dari peralatan yang dipergunakan dilapangan seperti GPS (Global Positioning System) yaitu alat untuk menentukan titik koordinat pengambilan sampel, sendok tanah untuk mengambil sampel tanah, kantong-kantong plastik untuk mewadahi sampel yang diambil. Kegiatan di laboratorium menggunakan peralatan gelas dan bahan-bahan pembuat media nutrien agar untuk pertumbuhan bakteri yang dimodifikasi dengan penambahan $\mathrm{HgCl}_{2}$ dengan perbedaan taraf konsentrasi $5 \mathrm{ppm}, 10 \mathrm{ppm}$ dan $15 \mathrm{ppm}$. Metode yang digunakan untuk menghitung total bakteri tanah digunakan tehnik agar cawan, disebut juga dengan metode dilution-plate atau dilution-count pada medium agar padat. Sedangkan untuk menumbuhkan mikroba hasil pengenceran di dalam cawan petri dilakukan dengan metode tuang (pour plate count).

Peralatan gelas gelas yang dipergunakan diantaranya adalah petri dish, tabung reaksi, rak tabung reaksi, jarum ose, erlenmeyer $250 \mathrm{ml}$, beaker glass $1000 \mathrm{ml}$, laminar air flow, autoclave, incubator, oven dan analytical balance. Bahan untuk pembuatan media pertumbuhan bakteri adalah media nutrient agar. Bahan-bahan yang dipergunakan untuk media nutrient agar adalah Beef ekstrak 3 gram, Pepton 5 gram, bacto agar 15 gram dan Aquades.

Metode yang digunakan adalah metode eksperiment skala laboratorium dan hasil yang diperoleh ditabulasikan kemudian disajikan secara deskriptif. Sampel diperoleh dari lokasi lahan yang dibedakan berdasarkan usia penggunaan lahan yaitu : Lahan penambangan aktif yang digunakan antara $0-2,5$ tahun (lokasi I), lahan penambangan aktif yang digunakan antara 2,5 - 5 tahun (Lokasi II) dan lahan yang sudah ditinggalkan lebih dari 5 tahun (Lokasi III). Masing-masing sampel tanah yang diperoleh dari lapangan dibuat seri pengenceran untuk mempermudah pengamatan bakteri yang tumbuh. Masing-masing sampel dibuat sampai pada pengenceran $10^{5} \mathrm{cfu} / \mathrm{ml}$. Setiap sampel pada taraf pengenceran tersebut diisolasikan pada media dengan penambahan $\mathrm{Hg} \mathrm{Cl}_{2}$ yang berbeda konsentrasinya yaitu mulai dari 5 ppm, 10 ppm dan 15 ppm. Tiap perlakuan diulang sebanyak 3 kali.

Pertumbuhan bakteri yang diamati adalah semua tipe bakteri yang tumbuh pada tiap-tiap cawan petri. Ciri-ciri bakteri yang tumbuh diamati secara visual dengan panduan buku karakterisasi koloni bakteri untuk mengamati bakteri secara fisik yaitu bentuk tumbuhnya, permukaan, bentuk pinggir, elevasi dan warna. Bakteri yang tumbuh dengan menunjukkan ciri membentuk zona bening disekitar tumbuhnya diukur dengan menggunakan jangka sorong dan dihitung dengan menggunakan rumus luas lingkaran yaitu $L=\pi r^{2}$ dalam satuan luas $\mathrm{mm}^{2}$.

\section{HASIL DAN PEMBAHASAN}

\section{Kondisi Umum Wilayah Mandor}

Batas Administrasi wilayah Kabupaten Landak terletak pada batas koordinat $0^{0} 10^{\prime}-1^{0}$ 10' Lintang Utara dan $109^{0} 5^{\prime}-110^{\circ} 10^{\prime}$ Bujur Timur. Kecamatan Mandor termasuk salah satu dari 13 kecamatan di Kabupaten Landak. Luas wilayah Kabupaten Landak secara keseluruhan 9.909,10 $\mathrm{Km}^{2}$ atau setara dengan $6,75 \%$ luas wilayah Provinsi Kalimantan Barat. Kecamatan itu adalah: Kecamatan Ngabang, Kecamatan Sengah Temila, Kecamatan Menyuke, Kecamatan Menjalin, Kecamatan Mandor, Kecamatan Mepawah Hulu, Kecamatan Meranti, Kecamatan Kuala Behe, Kecamatan Air Besar, Kecamatan Sebangki, Kecamatan Benyuke Hulu, Kecamatan Jelimpo, Kecamatan Sompak.

\section{Kondisi Umum Lokasi Penelitian}

Lokasi I adalah lahan penambangan aktif yang digunakan masyarakat antara 0 sampai 2,5 tahun,terletak di Desa Simpang Kasturi. Lahan ini baru dibuka untuk dijadikan lahan penambangan oleh masyarakat setempat. Vegetasi pada lokasi ini masih terlihat baik. Tumbuh-tumbuhan yang menutupi wilayah ini adalah jenis tanaman akasia, simpur, jenis tanaman perdu seperti paku-pakuan berdaun lebar dan keras, melastoma dan rumput-rumputan. Tipe tanah pada lokasi ini 
jenis tanah liat berpasir. Disekitar mesin dompleng atau tempat aktifitas pengerukan tanah terdapat lahan yang membentuk kolam dan genangan air yang keruh.

Lokasi II adalah penambangan aktif yang digunakan masyarakat antara 2,5 sampai 5 tahun. Terletak di Desa Mandor, tidak jauh dari makam juang Mandor.Lahan ini sudah dikerjakan oleh masyarakat setempat selama 3 tahun lebih.

Wilayah yang terbuka pada lokasi ini lebih luas, karena vegetasi banyak yang sudah kering dan kritis.

Lokasi III adalah lokasi penambangan yang sudah ditinggalkan lebih dari 5 tahun. Lokasi ini terletak di Desa Simpang Kasturi dimana pada kedua sisi badan jalan telah dipergunakan masyarakat untuk usaha perkebunan. Lokasi ini sekarang dimanfaatkan oleh masyarakat untuk perkebunan. Terlihat jenis tanaman yang ditanam oleh masyarakat setempat seperti, kelapa sawit dan pohon karet.

\section{Keragaman Bakteri}

Populasi bakteri yang hidup dapat diketahui dengan menghitung langsung jumlah keseluruhan bakteri yang hidup pada permukaan lempeng agar. Populasi bakteri diencerkan dalam larutan yang tidak toksik kemudian disebarkan pada media nutrien agar. Setelah inkubasi setiap unit yang hidup akan membentuk satu koloni selanjutnya disebut isolat. Jumlah individu yang hidup atau cluster yang ada ditentukan dari jumlah koloni dan pengenceran. Pengambilan sampel diperoleh dari tiga lokasi lahan yang dikriteriakan sebagai lahan yang baru digunakan dengan usia pemakaian 0 tahun sampai 2,5 tahun (lokasi I), lahan digunakan antara usia penggunaan 2,5 tahun sampai 5 tahun (lokasi II) dan lahan yang telah ditinggalkan diatas 5 tahun (lokasi III).

Hasil pengamatan populasi bakteri secara visual diperoleh sebanyak 20 isolat. Isolat-isolat yang terkarakterisasi dibedakan berdasarkan bentuk koloni, bentuk pinggir koloni, kemiringan serta warna tampilannya. Hasil pengamatan keragaman bakteri menunjukkan bahwa kemampuan isolat yang tumbuh mampu beradaptasi sampai pada konsentrasi 15 ppm $\mathrm{Hg}$, jumlah koloni yang teramati dalam $10^{5} \mathrm{cfu} / \mathrm{ml}$ dengan ciri masing-masing isolat. Terdapat beberapa isolat yang diindikasikan dapat mereduksi metil merkuri yang ditandai dengan terbentuknya zona bening berserta sebarannya. Untuk melihat keragaman bakteri berdasarkan usia penggunaan lahan pada lokasi penelitian disajikan pada Tabel 1 sebagai berikut.

Tabel 1. Keragaman Bakteri Berdasarkan Usia Penggunaan Lahan

\begin{tabular}{|c|c|c|c|}
\hline Lokasi & $\begin{array}{l}\text { Jenis } \\
\text { Isolat }\end{array}$ & $\begin{array}{c}\text { Jumlah } \\
\text { Individu }\end{array}$ & Frekuensi \\
\hline \multirow{14}{*}{$\begin{array}{l}\text { Lahan } \\
\text { penambangan } \\
\text { aktif usia } \\
\text { penggunaan } \\
\text { antara } 0-2,5 \\
\text { tahun }\end{array}$} & 1 & 19 & 0,17 \\
\hline & 2 & 6 & 0,05 \\
\hline & 3 & 5 & 0,04 \\
\hline & 4 & 4 & 0,03 \\
\hline & 5 & 3 & 0,02 \\
\hline & 6 & 6 & 0,05 \\
\hline & 7 & 3 & 0,02 \\
\hline & 8 & 8 & 0,07 \\
\hline & 11 & 4 & 0,05 \\
\hline & 13 & 25 & 0,23 \\
\hline & 14 & 6 & 0,05 \\
\hline & 16 & 7 & 0,06 \\
\hline & 17 & 6 & 0,05 \\
\hline & 18 & 6 & 0,05 \\
\hline \multicolumn{2}{|c|}{ Jumlah jenis isolat 14} & \multicolumn{2}{|c|}{ Total individu 108} \\
\hline & 1 & 15 & 0,10 \\
\hline & 6 & 8 & 0,05 \\
\hline & 7 & 7 & 0,04 \\
\hline & 8 & 5 & 0,03 \\
\hline Lahan & 9 & 34 & 0,22 \\
\hline penambangan & 10 & 13 & 0,08 \\
\hline aktif usia & 11 & 6 & 0,04 \\
\hline penggunaan & 12 & 4 & 0,02 \\
\hline antara $2,5-$ & 13 & 27 & 0,18 \\
\hline \multirow[t]{5}{*}{5 tahun } & 14 & 8 & 0,05 \\
\hline & 15 & 9 & 0,06 \\
\hline & 17 & 5 & 0,03 \\
\hline & 18 & 5 & 0,03 \\
\hline & 19 & 2 & 0,01 \\
\hline \multicolumn{2}{|c|}{ Jumlah jenis isolat 14} & \multicolumn{2}{|c|}{ Total individu 148} \\
\hline & 1 & 48 & 0,39 \\
\hline Lahan & 2 & 6 & 0,04 \\
\hline penambangan & 3 & 5 & 0,04 \\
\hline yang telah & 7 & 7 & 0,05 \\
\hline ditinggalkan & 9 & 36 & 0,29 \\
\hline lebih dari 5 & 10 & 9 & 0,07 \\
\hline \multirow[t]{2}{*}{ tahun } & 16 & 3 & 0,02 \\
\hline & 20 & 8 & 0,06 \\
\hline Jumlah jenis isolat & 8 & \multicolumn{2}{|c|}{ Total individu 122} \\
\hline \multicolumn{4}{|c|}{$\begin{array}{l}\text { Keterangan : Isolat adalah bakteri dengan cirri } \\
\text { tertentu yang tumbuh pada } \\
\text { media nutrien agar hasil } \\
\text { percobaan. }\end{array}$} \\
\hline
\end{tabular}


Tabel 1 memperlihatkan jenis-jenis isolat yang teramati, jumlah individu yang terdapat pada masing-masing lokasi dan frekuensi keberadaan isolat tersebut pada tiap-tiap lokasi. Pada lokasi I terlihat keberadaan frekuensi terendah adalah isolat 7 dan isolat 5 dimana frekuensi keberadaan kedua isolat ini dengan nilai 0,02 . Ini menunjukkan bahwa isolat ini sangat jarang terdapat pada lokasi I. Sedangkan isolat 13 adalah isolat dengan nilai terbesar 0,23 dibanding isolat-isolat lain. Ini berarti isolat 13 adalah isolat yang paling mendominasi pada lokasi I. Ini berarti bahwa isolat 13 adalah isolat yang paling sering muncul atau ditemukan pada lokasi I atau populasi isolat ini cukup tinggi karena lingkungannya mampu menopang pertumbuhannya. Sedangkan isolat-isolat lain frekuensi keberadaannya bervariasi seperti yang dapat dilihat pada tabel 1. Isolat dengan frekuensi terendah pada lokasi II adalah isolat 19, dengan nilai keberadaannnya 0,01. Ini menunjukkan isolat ini sangat jarang terdapat pada lokasi II atau isolat ini sangat sulit untuk tumbuh dan berkembang pada lokasi ini. Sedangkan isolat yang paling sering didapat atau paling dominan pada lokasi ini adalah isolat 9 dengan nilai 0,22 . Ini menunjukkan bahwa isolat 9 pada lokasi II merupakan isolat yang mampu tumbuh dan berkembang dengan baik pada lokasi ini dibanding lokasi lainnya. Untuk isolat-isolat lain pada lokasi II, frekuensinya dapat dilihat pada tabel 1 . Sedangkan untuk lokasi III, frekuensi isolat yang sangat rendah adalah isolat 16 dengan nilai 0,02 yang menandakan bahwa isolat ini adalah isolat yang sangat jarang terdapat pada lokasi ini. Sedangkan isolat dengan frekuensi tertinggi keberadaannya adalah isolat 1 dengan nilai 0,39 yang berarti isolat 1 sangat dominan terdapat pada lokasi ini. Berarti isolat 16 adalah isolat yang sangat sering ditemukan atau isolat yang mampu tumbuh dan berkembang dengan baik pada lokasi ini. Dari frekuensi keberadaan isolat yang berbeda-beda dari tiap lokasi dapat dilihat isolat-isolat yang paling jarang dan yang paling dominan atau populasinya paling banyak terdapat pada masing-masing lokasi penelitian.

Nilai frekuensi yang terlihat pada tabel 1 juga dapat menunjukkan sebaran isolat yang mendominasi pada satu lokasi namun sangat jarang ditemukan pada lokasi lain. Misalnya isolat 1 pada lokasi penambangan aktif antara 0 - 2,5 tahun, frekuensinya adalah 0,17 sedangkan pada lokasi penambangan 2,5 - 5 tahun frekuensinya adalah 0,10 . sedangkan pada lokasi penambangan yang telah ditinggalkan lebih dari 5 tahun frekuensinya 0,39 (paling dominasi pada lokasi III). Ini menunjukkan bahwa sebarannya terdapat pada tiga lokasi yang berbeda namun lokasi yang spesifik untuk pertumbuhannya adalah lokasi penambangan yang sudah ditinggalkan lebih dari 5 tahun. Ini menunjukkan bahwa kriteria lahan sangat berhubungan dengan keberadaan bakteri, atau peran terbesar adalah faktor lingkungan dalam menyeleksi mikroba. Lingkunganlah yang memilih jenis mikroba apa saja yang dapat hidup dan berkembang dalam suatu ekosisitem tanah. Untuk memperjelas isolat yang sering terdapat pada lokasi-lokasi yang berbeda, ditampilkan pada Tabel 2 yang akan menunjukkan skor kemunculan isolat yang teramati berdasarkan sebarannya pada tiap-tiap lokasi penelitian.

Tabel 2 menunjukkan bahwa dari 20 isolat hasil pengamatan diperoleh beberapa isolat hidup tersebar di tiga lokasi pengambilan sampel. Selanjutnya dikatakan sebagai isolat dengan skor 3 atau isolat yang mampu hidup di semua lokasi, skor 2 adalah isolat yang hanya terdapat pada dua lokasi yang berbeda dan skor 1 adalah isolat yang hanya terdapat pada satu lokasi saja. Dari 20 isolat yang diamati, isolat dengan skor 3 adalah isolat kode 1 dan 7. Artinya isolat ini adalah isolat yang hidup dengan kondisi yang berbeda berdasarkan umur penggunaan lahan penambangan. Isolat dengan skor 2 berdasarkan tabel 2 adalah isolat 2 , isolat 8 , isolat 9 , isolat 10 , isolat 11 , isolat 13 , isolat 14 , isolat 15 , isolat 16 , isolat 17 dan 18. Ini menunjukkan bahwa isolat-isolat tersebut hanya bisa berada pada kondisi tertentu berdasarkan kriteria lahan penelitian. Sedangkan isolat dengan skor 1 adalah isolat yang sebaran hidupnya hanya berada pada satu tipe lokasi saja. Isolat tersebut adalah isolat 2, isolat, 3 isolat 4 , isolat 5 , isolat 6 , isolat 12 , isolat 19 dan isolat 20. Jika dilihat tabel 1 dan Tabel 2 akan terlihat jenis isolat yang mampu hidup di lokasi yang berbeda menurut usia penggunaannya atau memiliki skor 3, yaitu isolat 1 dan isolat 3 . Diantara keduanya, isolat yang diduga memiliki kemampuan mereduksi metil merkuri adalah isolat 3. Artinya dari dua tipe isolat yang mampu hidup pada tiga lokasi dengan kriteria yang berbeda namun hanya isolat 3 yang tahan terhadap paparan merkuri. 
Tabel 2. Skor Kemunculan Isolat dari 3 Lokasi

\begin{tabular}{|c|c|c|c|c|c|}
\hline \multirow{2}{*}{$\begin{array}{l}\text { Kode } \\
\text { Isolat }\end{array}$} & \multicolumn{3}{|c|}{ Asal lokasi } & \multirow{2}{*}{ Skor Kemunculan } & \multirow{2}{*}{ Keterangan Lain } \\
\hline & I & II & III & & \\
\hline 1 & $\sqrt{ }$ & $\sqrt{ }$ & $\sqrt{ }$ & 3 & \\
\hline 2 & $\sqrt{ }$ & - & $\sqrt{ }$ & 2 & \\
\hline 3 & $\sqrt{ }$ & - & - & 1 & \\
\hline 4 & - & $\sqrt{ }$ & - & 1 & \\
\hline 5 & $\sqrt{ }$ & - & - & 1 & Ada zona bening \\
\hline 6 & $\sqrt{ }$ & - & - & 1 & \\
\hline 7 & $\sqrt{ }$ & $\sqrt{ }$ & $\sqrt{ }$ & 3 & Ada zona bening \\
\hline 8 & $\sqrt{ }$ & $\sqrt{ }$ & - & 2 & \\
\hline 9 & - & $\sqrt{ }$ & $\sqrt{ }$ & 2 & \\
\hline 10 & - & $\sqrt{ }$ & $\sqrt{ }$ & 2 & \\
\hline 11 & $\sqrt{ }$ & $\sqrt{ }$ & - & 2 & Ada zona bening \\
\hline 12 & - & $\sqrt{ }$ & - & 1 & \\
\hline 13 & $\sqrt{ }$ & $\sqrt{ }$ & - & 2 & Ada zona bening \\
\hline 14 & $\sqrt{ }$ & $\sqrt{ }$ & - & 2 & \\
\hline 15 & $\sqrt{ }$ & $\sqrt{ }$ & - & 2 & \\
\hline 16 & $\sqrt{ }$ & - & $\sqrt{ }$ & 2 & Ada zona bening \\
\hline 17 & $\sqrt{ }$ & $\sqrt{ }$ & - & 2 & \\
\hline 18 & $\sqrt{ }$ & $\sqrt{ }$ & - & 2 & \\
\hline 19 & - & $\sqrt{ }$ & - & 1 & \\
\hline 20 & - & - & $\sqrt{ }$ & 1 & Ada zona bening \\
\hline
\end{tabular}

Tabel 3. Ciri-Ciri Isolat yang Memiliki Kemampuan Mereduksi Metil Merkuri dari Beberapa Lokasi

\begin{tabular}{|c|c|c|c|c|c|c|c|c|c|}
\hline \multirow[t]{2}{*}{ No } & \multirow{2}{*}{$\begin{array}{l}\text { Kode } \\
\text { Isolat }\end{array}$} & \multicolumn{4}{|c|}{ Ciri-ciri fisik } & \multicolumn{3}{|c|}{ Asal lokasi } & \multirow[t]{2}{*}{ Lain- lain } \\
\hline & & Bentuk & Kemiringan & Pinggir & Warna & I & II & III & \\
\hline 1. & 5 & Irregular & Pulvinate & Undulate & Kekuningan & $\sqrt{ }$ & - & - & $\begin{array}{c}\text { Ada zona } \\
\text { bening }\end{array}$ \\
\hline 2. & 7 & Irregular & Flat & Entire & Putih bening & $\sqrt{ }$ & $\sqrt{ }$ & $\sqrt{ }$ & $\begin{array}{c}\text { Ada zona } \\
\text { bening }\end{array}$ \\
\hline 3. & 11 & Circular & Umbonate & Entire & $\begin{array}{c}\text { Putih } \\
\text { kecoklatan }\end{array}$ & $\sqrt{ }$ & $\sqrt{ }$ & - & $\begin{array}{c}\text { Ada zona } \\
\text { bening }\end{array}$ \\
\hline 4. & 13 & Circular & Flat & Entire & Bening & $\sqrt{ }$ & $\sqrt{ }$ & - & $\begin{array}{c}\text { Ada zona } \\
\text { bening }\end{array}$ \\
\hline 5. & 16 & Irregular & Flat & lobate & Bening & $\sqrt{ }$ & - & $\sqrt{ }$ & $\begin{array}{c}\text { Ada zona } \\
\text { bening }\end{array}$ \\
\hline 6. & 20 & Rhizoid & Flat & Lobate & $\begin{array}{l}\text { Coklat } \\
\text { bening }\end{array}$ & - & - & $\sqrt{ }$ & $\begin{array}{c}\text { Ada zona } \\
\text { bening }\end{array}$ \\
\hline
\end{tabular}

Tabel 3 menunjukkan ciri-ciri isolat yang memiliki kemampuan mereduksi metil merkuri dan sebarannya dari beberapa lokasi dengan kriteria penggunaan lahan penambangan yang berbeda. Kemampuan mereduksi metil merkuri dilihat dari bentukan zona bening yang dihasilkan pada media pertumbuhan dengan penambahan $\mathrm{HgCl}_{2}$ mulai dari 5 ppm, $10 \mathrm{ppm}$ dan $15 \mathrm{ppm}$.

Kemampuan isolat dari beberapa lokasi yang berbeda dalam mereduksi metil merkuri pada konsentrasi -konsentrasi yang diujikan ditampilkan pada Tabel 4. 
Tabel 4. Keragaman Bakteri Berdasarkan Kemampuan Mereduksi Hg

\begin{tabular}{|c|c|c|c|}
\hline Konsentrasi $\mathrm{Hg}$ & $\begin{array}{l}\text { Jenis } \\
\text { Isolat }\end{array}$ & Jumlah Individu & Frekuensi \\
\hline \multirow{4}{*}{$5 \mathrm{ppm}$} & 7 & 1 & 0,21 \\
\hline & 11 & 6 & 0,18 \\
\hline & 13 & 19 & 0,59 \\
\hline & 16 & 6 & 0,18 \\
\hline Jumlah jenis isolat & 4 & & \\
\hline \multirow{6}{*}{$10 \mathrm{ppm}$} & 5 & 3 & 0,06 \\
\hline & 7 & 12 & 0,26 \\
\hline & 11 & 4 & 0,08 \\
\hline & 13 & 22 & 0,47 \\
\hline & 16 & 2 & 0,04 \\
\hline & 20 & 3 & 0,06 \\
\hline Jumlah jenis isolat & 6 & & \\
\hline \multirow{4}{*}{$15 \mathrm{ppm}$} & 13 & 11 & 0,45 \\
\hline & 16 & 7 & 0,29 \\
\hline & 7 & 4 & 0,16 \\
\hline & 20 & 2 & 0,08 \\
\hline Jumlah jenis isolat & 4 & & \\
\hline
\end{tabular}

Tabel 4 menunjukkan keragaman isolat dari beberapa lokasi penelitian yang memiliki kemampuan mereduksi metil merkuri dengan frekuensi keberadaannya dalam paparan merkuri yang diujikan. Frekuensi dua isolat mendominasi yang terdapat pada taraf konsentrasi 5 ppm, 10 ppm dan 15 ppm adalah isolat 7 dan isolat 13. Pada konsentrasi 5 ppm isolat 7 dengan nilai frekuensi 0,21 dan isolat 13 dengan niai 0,59. Pada konsentrasi 10 ppm, frekuensi isolat 7 adalah 0,26 sedangkan isolat 13 sebesar 0,47. Pada taraf konsentrasi 15 ppm, nilai frekuensi isolat 7 adalah 0,16 sedangkan nilai frekuensi isolat 13 adalah 0,45 . Dalam perbedaan taraf konsentrasi $\mathrm{Hg}$ tersebut, kedua isolat menunjukkan nilai frekuensi yang semakin menurun, karena pada taraf uji 15 ppm $\mathrm{Hg}$ semua isolat menunjukkan nilai frekuensi semakin mengecil. Hal ini disebabkan karena semakin tinggi konsentrasi $\mathrm{Hg}$ diberikan dalam media pertumbuhan bakteri semakin besar tingkat kepunahan bakteri terjadi, bakeri mempunyai kemampuan terbatas dalam mentolerir polutan pada habitatnya. Peningkatan kadar polutan yang semakin tinggi akan menyebabkan semakin tinggi tinggi tingkat kepunahan bakteri karena tidak mampu mentolerir keberadaan polutan tersebut. Seperti yang dikemukan oleh Tapan et al. (1992), bahwa bakteri yang tahan terhadap logam berat adalah bakteri yang telah beradaptasi terhadap lingkungan yang tercemar logam berat.

\section{Indikasi Hg Tereduksi}

Bakteri yang ditumbuhkan dalam media yang mengandung merkuri akan mengalami stress pada awalnya akibat senyawa toksik tersebut. Stress ini akan ditanggapi dengan adaptasi lingkungan yaitu pertumbuhan yang lambat. Selama proses adaptasi terjadi, perubahan senyawa didalam sel dilakukan oleh enzim dan akan terjadi perubahan kecepatan dan jalur metabolisme (Suheryanto, dkk. 2006). Enzim-enzim yang diproduksi oleh bakteri memodifikasi polutan beracun dengan mengubah struktur kimia polutan tersebut (biotransformasi) dimana polutan tersebut menjadi terdegradasi, strukturnya menjadi tidak kompleks dan akhirnya menjadi metabolit yang tidak beracun.

Daya reduksi yang ditunjukkan oleh bakteri yang diindikasikan mampu mendegradasi metil merkuri pada media dengan penambahan $\mathrm{Hg}$, ditunjukkan dengan bentukan zona bening disekitar tumbuhnya bakteri. Luas zona bening dari hasil berbagai konsentrasi $\mathrm{Hg}$ memperlihatkan hasil reduksi bakteri lokal yang terdapat di Desa Mandor dapat dilihat pada Gambar 1. 


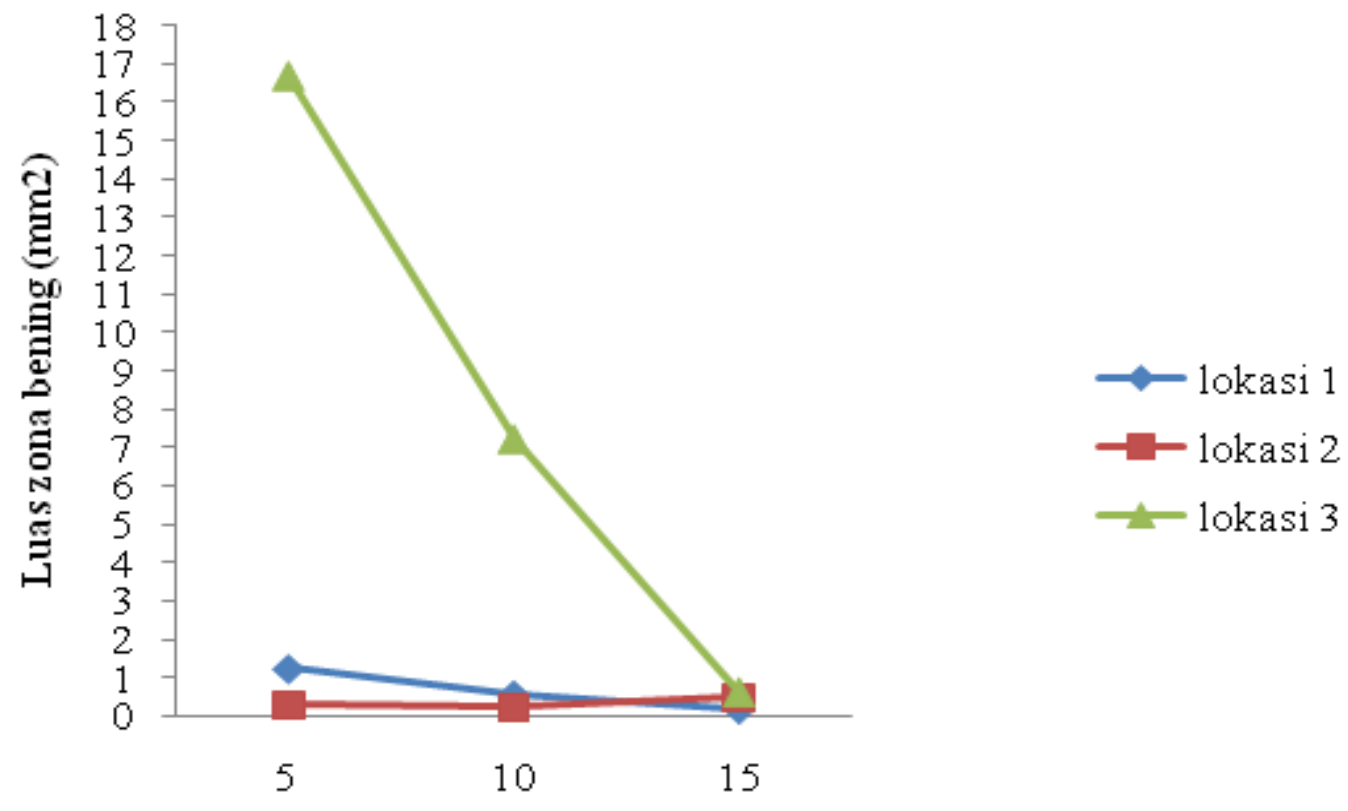

Konsentrasi Hg (ppm)

Gambar 1. Kemampuan Isolat 7 Dari Beberapa Lokasi Penambangan Dalam Mereduksi Hg bedasarkan Luas Zona Bening Pada media Nutrien Agar.

Gambar 1 memperlihatkan kemampuan isolat 7 untuk membentuk zona bening pada beberapa perlakuan konsentrasi $\mathrm{Hg}$ dalam media pertumbuhan sangat berbeda terutama isolat yang berasal dari lokasi 3. Kemampuan membentuk zona bening pada konsentrasi 5 ppm $\mathrm{Hg}$ sangat besar dibanding dengan bentukan zona bening dari lokasi I dan lokasi II. Namun pada konsentrasi 15 ppm $\mathrm{Hg}$ semua bakteri yang berasal dari lokasi yang berbeda menunjukkan kemampuan yang berkurang dalam membentuk zona bening. Semakin tinggi konsentrasi $\mathrm{Hg}$ maka kemampuan membentuk zona bening semakin kecil. Hal ini menunjukkan bahwa isolat yang berasal dari lokasi III dapat beradaptasi dengan nilai konsentrasi $\mathrm{Hg}$ yang rendah dan semakin berkurang seiring dengan meningkatnya kadar merkuri. Pada konsentrasi $15 \mathrm{ppm} \mathrm{Hg}$, kemampuan isolat 7 dari berbagai lokasi semakin berkurang dalam membentu zona bening. Hal ini disebabkan karena bakteri mempunyai kemampuan terbatas dalam mentolerir keberadaan polutan. Semakin tinggi kadar $\mathrm{Hg}$ maka akan semakin besar tingkat kematian isolat terjadi. Hal ini dapat dilihat dari besar kecilnya luas zona bening yang terbentuk dari berbagai tingkat konsentrasi.
Semua bakteri yang hidup pada tanah atau air umumnya mempunyai kemampuan untuk membersihkan polutan yang ada pada lingkungannya, asalkan kecepatan masuk polutan dan kemampuan bakteri mereduksinya berjalan seimbang, disebut juga dengan istilah daya lenting. Bakteri yang berada pada tiga lokasi tersebut menunjukkan bahwa bakteri yang diisolasikan pada media pertumbuhan dapat mereduksi metil merkuri dari konsentrasi yang diujikan. Hal ini disebabkan karena bakteri memiliki sifat yang resisten terhadap metil merkuri akan memproduksi enzim, organo merkuriliase yang berfungsi memutus ikatan $\mathrm{CH}_{3}-\mathrm{Hg}^{+}$menjadi $\mathrm{CH}_{4}$ dan $\mathrm{Hg}^{2+}$.

Perbedaan kemampuan bakteri hidup pada konsentrasi merkuri yang berbeda dari tiap lokasi dipengaruhi banyak faktor, salah satunya adalah kadar merkuri, seperti yang dikemukan oleh Hughes \& Poole (1998) mengatakan bahwa resistensi setiap bakteri terhadap keberadaan merkuri ditanggapi dengan berbagai cara. Ada tiga mekanisme respon terhadap strees merkuri. Pertama dengan cara biotransformasi (melalui oksidasi-reduksi). Kedua dengan cara biopresipitasi (ion logam dipresipitasikan pada permukaan sel melalui mekanisme mikrobial seperti efflux kation atau 
mengubah $\mathrm{pH}$ ). Ketiga dengan biosorbpsi (menggunakan biomas mikrobia alami atau rekombinan untuk adsorpsi ion metal).

Keberadaan gen yang resisten terhadap merkuri berhubungan langsung dengan lamanya kandungan $\mathrm{Hg}$ yang berada pada lokasi penambangan. Tingginya tingkat kontaminasi $\mathrm{Hg}$ pada suatu daerah akan menginduksi sel bakteri untuk menerima gen resisten merkuri dari lingkungan.

Zona bening yang terbentuk diindikasikan sebagai kemampuan isolat dalam mereduksi metil merkuri. Kemampuan isolat mereduksi metilmerkuri dengan perbedaan konsentrasi dari 3 lokasi menunjukkan tipe atau cirinya yang dapat dilihat secara fisik. Jika dilihat dari usia aktifitas lahan yang dipergunakan untuk pertambangan emas, maka isolat-isolat yang diisolasi dari tiga lokasi tersebut dapat menunjukkan kemampuan untuk membentuk zona bening. Hal ini karena isolat yang tumbuh adalah isolat yang mempunyai kemampuan mereduksi metil merkuri yang ditambahkan pada media pertumbuhan dengan beberapa tingkatan konsentrasi $\mathrm{Hg}$.

Bakteri yang tahan hidup pada daerah yang tercemar metil merkuri adalah bakteri yang memiliki kemampuan merubah logam merkuri ditanah menjadi merkuri organik oleh aktifitas mikrobia fotosintetis (Prasetyawati, 2009). Hasil penelitian menunjukkan kemampuan bakteri mereduksi metil merkuri dari beberapa lokasi pengambilan sampel. Bakteri memiliki sifat-sifat baik secara fisiologis maupun enzimatis untuk mentolerir keadaan habitatnya. Kemampuan bakteri dalam mereduksi metil merkuri dapat dilihat dari kemampuannya hidup pada konsentrasi $\mathrm{Hg}$ yang ditingkatkan sampai pada konsentrasi tertinggi percobaan ini yaitu $15 \mathrm{ppm} \mathrm{Hg}$. Zona bening yang terbentuk menunjukkan bahwa mulai dari konsentrasi 5 ppm $\mathrm{Hg}$ sampai 15 ppm $\mathrm{Hg}$, bakteri masih bisa tumbuh menurut Prasetyawati (2009). Bakteri yang masih bisa tumbuh dalam kandungan konsentrasi merkuri tinggi diduga memiliki sistem enzim spesifik untuk mendetoksifikasi $\mathrm{HgCl}_{2}$ sehingga terakumulasi menjadi bentuk lain. Gadd (2000) mengatakan bahwa bakteri yang hidup pada situs habitat yang mengalami kontaminasi akibat keberadaan logam berat mengembangkan beberapa toleransi terhadap logam berat dengan cara kompleksasi meliputi produksi polisakarida ektraselular yang memiliki sifat-sifat anion yang berfungsi sebagai bioakumulator yang efisien, produksi metabolit organik yang memiliki sifat pengkelat dan membentuk kompleks dengan logam, presipitasi serta kristalisasi ekstraseluler oleh bakteri pereduksi sulfat seehingga membentuk deposit sulfide yang kaya akan logam dan pembentukan metalotheonin (dalam sel dapat meningkatkan logam) yang berfungsi untuk detoksifikasi, penyimpanan dan regulasi ion logam dalam sel. Proses detoksifikasi merkuri oleh bakteri kerja enzim merkuriliase dengan cara memutuskan ikatan karbon-merkuri seperti pada senyawa metil $\left(\mathrm{CH}_{3} \mathrm{Hg}^{+}\right)$dan senyawa etil $\left(\mathrm{C}_{6} \mathrm{H}_{5} \mathrm{Hg}^{+}\right)$ menjadi senyawa $\mathrm{Hg}^{2+}$ yang kemudian direduksi oleh enzim merkuri reduktase menjadi $\mathrm{Hg}^{0}$ (Hughes dan Poole, 1989).

\section{Prosentase Bakteri Pereduksi}

Keragaman bakteri yang diamati
berdasarkan perbedaan usia lahan penambangan baik yang aktif digunakan maupun yang telah ditinggalkanlebih dari lima tahun, diperoleh sebanyak 20 isolat yang tersebar dalam tiga lokasi tersebut (tabel 4). Diantara isolat-isolat yang teramati, diperoleh isolat yang memiliki kemampuan mereduksi metil merkuri. Prosentase sebaran isolat yang memiliki kemampuan mereduksi metil merkuri pada lokasi penambangan aktif usia penggunaan lahan 0 - 2,5 tahun adalah sebesar $33 \%$. Pada lokasi penambangan aktif usia penggunaan lahan antara 2-5 - 5 tahun adalah sebesar $21 \%$. dan untuk lahan penambangan yang telah ditinggalkan lebih dari 5 tahun adalah $25 \%$. Hal ini menunjukkan semakin besar keragaman bakteri yang terdapat pada lokasi yang tercemar merkuri semakin besar kemungkinan terdapat bakteri yang memiliki kemampuan mereduksi metil merkuri.

\section{SIMPULAN}

Hasil penelitian keragaman bakteri lokal asal Desa Mandor yang mempunyai kemampuan dalam mereduksi metil merkuri dari lahan yang berbeda usia penggunaannya, dapat disimpulkan sebagai berikut :

a. Bakteri lokal asal Kecamatan Mandor yang dominan terdapat pada lokasi penambangan aktif antara 0 sampai 2,5 tahun adalah : isolat 13 dan isolat 1. Pada lokasi 
penambangan aktif usia penggunaan lahan antara 2,5 sampai 5 tahun adalah isolat 9 dan isolat 13. dan pada lokasi penambangan yang telah ditinggalkan lebih dari 5 tahun, isolat yang dominan adalah isolat 1 dan isolat 9 .

b. Isolat bakteri yang mampu mereduksi $\mathrm{Hg}$ adalah pada lokasi penambangan aktif usia penggunaan lahan antara $0-2,5$ tahun adalah isolat 5 , isolat 7 , isolat 11 , isolat 13 dan isolat 16. Lokasi lahan penambangan aktif usia penggunaan lahan antara 2,5 - 5 tahun adalah isolat 7, isolat 11 dan isolat 13 . Dan lahan penambangan yang telah ditinggalkan lebih dari 5 tahun adalah isolat 7 , isolat 16 dan isolat 20 .

c. Terdapat isolat yang memiliki kemampuan berbeda dalam mereduksi metil merkuri dari lahan yang berbeda, yaitu isolat 7 dan isolat 13.

d. Usia penggunaa lahan yang berbeda di Kecamatan Mandor menunjukkan perbedaan kemampuan bakteri indigenous dan sensifitasnya terhadap paparan metil merkuri berdasarkan karakteristik lahan dengan tutupan vegetasi yang masih baik, mulai kritis dan lahan yang didominasi satu tanaman tertentu atau perkebunan karet. Hasil paparan merkuri terhadap isolat bakteri juga direspon berbeda-beda atau terdapat isolat yang mampu mereduksi pada konsentrasi $5 \mathrm{ppm} \mathrm{Hg}$ atau $10 \mathrm{ppm}$, dan terdapat pula isolat yang mampu mereduksi $\mathrm{Hg}$ pada konsentrasi $15 \mathrm{ppm}$ yaitu isolat 20 yang hanya terdapat pada lokasi penambangan yang telah ditinggalkan lebih dari 5 tahun.

\section{DAFTAR PUSTAKA}

Ferianto, Burhanuddin, Widiastuti T. 2013. Kadar dan Sebaran Pencemaran Merkuri (Hg) Akibat Penambangan Emas Rakyat Di Lokasi Hutan Kerangas Kecamatan Mandor Kabupaten
Landak.jurnal.untan.ac.id/index.php/jmf kh/article/view/2767/2746.1(2).

Gadd, M.2000. Heavy Metal Pollutants. Environmental and Biotechnology Espect Eucyclopedia of Microbiology $2^{\text {nd }}$ Ed.2: 607-617

Hughes,M.N and R.K. Poole. 1989. Metal and Microorganism. Chapman and Hall. London

Ijong, F. G., Dien, A H. 2011. Karakterisasi bakteri Pereduksi Metil Merkuri (Escherichia Coli) Diisolasi dari Perairan Pantai Teluk Manado. Jurnal Perikanan dan kelautan Tropis ( VII) 3.

Onrizal, 2005. Restorasi Lahan Terkontaminasi Logam Berat. http://library.usu.ac.id/download/fp/hut an-onrizal6.

Prasetyawati. E.T. 2009. Bakteri Rhizosfer Sebagai Pereduksi Dan Agensia Hayati.UPN Press. Jogjakarta.

Rawlings, DE. 2004. Microbially Assisted Dissolution Of Mineral and Its use in the Mining Industry. Pure Appl. Chem. 76(4) 847-859.

Suheryanto, Soetarto, S.E., Sugiharto, E., Djohan, T.S. 2006. Jurnal Pengelolaan Lingkungan \& Sumber Daya Alam, 5 (3), September.

Tapan K. Misra. 1992 Heavy Metal, Bacterial Resisten. Encyclopedia of Microbiologi Vol II. Academic Press. Inc. V

Zulaika, E., Prasetya, A.Y., Kuswytasari, D.N., (2012). Adaptasi Genera Bacillus Pada Media Yang Mengandung Logam Timbal. Scientific Conference Of Environmental science \& technology IX-2012. 10 Juli 2012. Surabaya 